\title{
Explorating the Leadership Landscape in Four Different Types of Greek Secondary Schools
}

\author{
Margarita Mansola \\ Educational Consultant \\ Greece
}

\begin{abstract}
According to latest OESD report, the Greek education system is faced with a lot of challenges, mostly with reference to weak educational outcomes [41]. The highly centralized system - despite some minor and quite modest attempts of decentralization is considered to be a possible drawback. The way school leaders are selected and appointed is closely linked to a diminishing view of school leadership, further strengthening the limited authority the Ministry acknowledges to school leaders. The present research aimed to explore this unmapped but crucially important area in Greek schools and argue on the key role of leadership, especially with reference to its effect on teachers' professionalism. Four types of secondary schools that differed in their respective contexts, systems of power and governance, were selected. Findings revealed that high centralization of power to the State was negatively received by all State School leaders who felt significantly deprived of their role to exercise leadership. Deviations from State control in all three other types of schools led to clear differences in the way Heads led, although this was not the single variable to which teachers' perceived realities could be attributed. It was suggested that special emphasis should be placed on strengthening leadership in schools and empowering teachers.
\end{abstract}

\section{Introduction}

It has been constantly documented in literature that good schools are a result of good leadership [12], [5] and that "leadership matters" [4]. Research in the United States (Brookover, Edmonds) and the United Kingdom (Mortimore, Rutter et al., Southworth), "highlights that effective leaders exercise a direct or indirect but powerful influence on the school's capacity to implement reforms and improve students' levels of achievement" [50]. In a review of relevant literature given by Vidony and Grassetti [50] it is stated that despite the fact that evidence mainly point to teacher performance as directly affecting students, it is the quality of leadership that largely affects the motivation of teachers and the quality of their teaching. The conclusions of the Council on efficiency and equity in education and training [41] also point to the quality of school leadership as one of the key factors for high quality learning outcomes. After reviewing a number of studies in Australia, Mulford also comes to the conclusion that leadership seems to have an indirect effect on school outcomes further commenting that leadership is about human behavior [38].

It has also been suggested that leadership in today's globalized societies, should be viewed as "a social and cultural process, embedded in its context" [12]. Such a conceptualization takes into account the international, regional and local context of schooling and suggests that effectively leading schools in these complex environments, presupposes a dynamic approach to leadership. The case of Greece is a rather interesting case to explore in this respect. Although leadership has been repeatedly mentioned in advisory papers as a dynamic factor for school improvement, together with alternative systems of governance and management, the Greek educational system is far from acknowledging importance to it [40], [41]. Moreover, despite the vast and radical changes that have taken place in the world and education in the 21st century, and the sharp increase of diversity in school population, accentuated by the refugee crisis, the way schools are run in Greece, has in general terms remained unchanged. Characterized by a highly centralized form of governance, tightly controlled by the State and having been judged as inefficient by almost everyone, both internally (community, teachers, leaders, politicians) and externally (experts' reports, advisors, consultants), the system, in practice is still the same. It should be clear by now then, that 
while there is relative unanimity in recognizing the effects of leadership on school outcomes, there is little agreement as to what is meant by leadership, how exactly it affects schooling and to what extent leadership refers to the Principals or the whole community. Moreover, to define leadership in schools, can be a rather hard task as not only do the definitions change and vary but so does the context in which leadership is applied [48]. At the same time, leadership is interwoven in so many activities that it is often hard to dissociate and analyze it in order to explore those intervening factors that make the difference. Consequently, when it comes to school leadership, there is little agreement even amongst leadership theorists themselves, on a definition. In fact, numerous classification systems and definitions have been developed, each indicating a different focus assigned by various theorists [17]. Bush and Glover have identified eight models of leadership each focusing on different aspects of how schools and people should be led [5]. Of these, the most widely acclaimed in recent literature is pedagogic leadership, later developed into Leadership for Learning which assumes a learning centered leadership principle for all. i.e students, teachers, community [43].

In an effort to define and explore more salient aspects of leadership in schools, Male and Paleologou suggest a model of pedagogical leadership which encompasses all social realities involved in school learning [34]. In their view, changes that take place in modern world and $21^{\text {st }}$ century education, affect our understanding of pedagogical praxis as defined by Freire [19] and needs be reviewed. They suggest that modern era requires critical judgment and thinking from the part of leaders of a kind that 'reflects pedagogy in a critical education science'. In their research with five most successful leaders, they found that what distinguished those leaders' work was a strong moral obligation to communities, improving self-esteem among staff and pupils and establishing core values for all [34]. In this conceptualization leadership becomes a moral issue where the leader manages to mobilize the passion and loyalty of teachers as well as parents and students [21], [46].

\section{Unwinding the Greek school micro and macro context.}

Schools operate in different contexts and are liable to both internal and external pressures. Thus, the present study aimed to investigate the ways leaders in the different micro and macro contexts tried to mobilize and accommodate the needs of their schools.

Following the literature reviewed, a number of variables were of interest as relevant to the Greek reality and this study: Professionalism, a term much acclaimed in recent writings on school leadership and strongly supported by Sergiovanni refers to the need of establishing a professional ethos to leaders who can then inspire teachers to become professionals [44]. It is believed that teachers' focus on their professional development and performance is directly linked to their perceived value as professionals. Georgas, Tsigou and Giannoukos argue in their research in Greek State secondary schools, that there has been a large de- professionalization of teachers as a result of a number of factors, such as the total absence of professional development and the political State practices that leave teaching almost entirely to teachers while at the same time tightly controlling the curriculum [22].

Moreover, in Greek State schools there is no room for upward mobility or any other form of development. This, according to Georgas et al, has been considered as a factor that deprives State school teachers of any incentive to strive for excellence [22]. This is not quite or at least not always the case in the other three types of schools (even in Model schools that are state run), where qualifications, experience and quality of work are taken under consideration. Sahlberg suggests that teachers' need for professional worth is a highly important factor and one that, it is hereby argued, is directly relevant to the way schools are led [47]. Years of experience in a particular school, was another variable of interest. Van Maele and Van Houtte explored this as a mediating factor for feelings of trust among faculty members in a school and concluded that there were positive associations between teacher trust in students, parents, colleagues, and the Principal and job satisfaction [49]. In Greek secondary State schools years of experience fluctuate as there is a peculiar system of seniority and of transferability that mostly affects younger teachers who frequently have to move between schools or work as adjunct teachers. Private schools on the other hand can offer long term relationships among staff members which may consequently have an effect on trust and perceived job satisfaction.

\subsection{A focus on learning}

Earley believes that viewing everyone in school as learners, builds a culture of learning that is manifested in all levels of a school [14]. This places particular emphasis on teachers as learners and on developing professionalism, which as documented in Robinson's studies carried out in New Zealand, had the greatest impact on students' learning [43].

Professional development has been widely proven to play a significant role in bringing about educational improvement and this is evident in research both in developed and developing countries. Especially with 
the emergence of the $21^{\text {st }}$ century the need for constant learning has surfaced and Continuous Professional Development (CPD) has become a priority for schools. Sergiovanni notes that schools that place value to learning direct their energy to continuous learning for teachers [44]. Similarly, according to Middlewood and Abbot schools have to build an ethos and a culture of lifelong learning, constantly developing and striving for improvement [36] .

At the same time, priorities for different school contexts do vary, while identifying and meeting the needs of staff as well as students still remains a hard task to accomplish. Earley and Porrit argue that there are still tensions in how we think about Professional Learning Development as we lack a universal • understanding of it, which largely explains the lack of a professional approach to how it should be led [16]. Hargreaves and Sebba cited in Porrit [42] draw attention to the fact that the traditional view of externally attended, passively receiving information is questionable as to its effectiveness, especially if by "effectiveness" we mean teachers' improved knowledge and skills embedded in their everyday teaching. An example of this skepticism is expressed by Guskey who introduces the necessity of evaluating CPD in schools and institutions as there seems to be little practical value of it [24]. Literature indicates more effective approaches, concerned with joint practice development, and collaborative forms of Professional Development [42].

2.1.1. Scope of Investigation. With the aim to analyze the ways different schools are led and explore the effects these differences may have on teachers, the present research addressed both a number of school leaders of the four different types of schools and their respective staff, though by means of different methodologies. The study drew upon Swaffield and MacBeath's 'Carpe Vitam' project, suggesting that leadership today must be shared, working environment stimulating and teachers given every opportunity to grow and develop professionally. The five principles a) focus on learning b) an environment for learning c) a learning dialogue d) shared leadership and e) shared accountability explored in that project were also of interest here [48].

Adopting the view that quality of staff influences the quality of the learning experience, separate focus was given to variables that, depending on the ways schools are led, influence this quality [47]. Special attention was given to Leadership for Learning, with the aim to highlight differences in both the conceptualization and implementation of teachers' professional development. Leadership for learning elaborates on the idea that learning relies on different systems, which are interconnected through leadership
[48]. Knapp names these levels of learning in his "wedding cake model" in which leadership appears to be the "connecting tissue" of student learning, professional learning, school learning and system learning [48]. Learning culture was then of high importance as it would also reflect possible mediating factors connected with variables examined.

Leadership styles were explored in the four participating secondary schools, with different degrees of deviation from the tight control of the State central governance. More precisely, the four different types of schools were:

\section{- State Schools:}

These operate under the close supervision of the State and are centrally controlled. Student admission is free of charge and based on geographical area (place of residence). State schools are led by a Head, an Assistant Head and the Teachers' Association, who are responsible for the operation of the school. School committees, comprised of local governors, one representative of Parent Association and a representative of the pupils manage the school budget. Teachers are centrally appointed by the State, every year, depending on annual needs for teaching staff, and paid by the State. A number of teachers are adjunct, which brings about a number of challenges for the operation of schools and for the professional commitment of teachers.

\section{- Model Schools:}

These are called "Model" or "Experimental" schools (here termed "Model"), are state run in terms of funding, thus free of charge for students but operate under a different framework that allows degrees of freedom from central State control.

This "freedom" is mostly concerned with student admission (selected by a lottery draw or entry exams), teaching staff (to be employed in this type of schools teachers must have additional qualifications, while they follow a different procedure of appointment) and are free to experiment with new programs of study and teaching methods. They cooperate closely with the Universities and are usually led by Heads with advanced qualifications. The academic curriculum is still controlled by the State but the School decides on ways to deliver it most effectively to meet student needs, designs additional educational programmes and is free to operate in a more student-centered manner. They are still managed by the same structure as State schools. Staff is paid by State. Private Schools operate in the private sector as concerns their organization and funding. They constitute the $5.5 \%$ of Greek schools and have absolute freedom as to the selection of their 
students, staff, internal policies and are entirely selffunded. Accordingly, they charge fees to their students. They are free to work on daily schedule as they feel it best suits their educational aims but are under the control of the State as to allocation of hours to specific subjects, use of text books and ways of delivering the subjects, depending on the level of control the State wishes to exercise. They fill a gap in Greek education system especially as concerns the teaching. Private schools generally follow the organizational structure of State schools (Head, Deputy Head, Teacher and Parent Association) but are free to exercise their role as judged. In reality, Heads and Deputy Heads are responsible for the everyday running of the school, and accountable to the owner and stakeholders including parents and pupils.

IB Schools $^{1}$ in Greece, are basically departments of Greek private schools operating at the upper high school level. Consequently, what applies in private schools in terms of funding, resources, school fees and accountability is also the case here. Additionally, the IB school can implement extra screening processes in student and staff selection since it involves a good level of English language skills for both and advanced competencies and qualifications for teachers. As concerns deviating from State control, the IB schools, although subject to Greek legislation, are also and foremost led by to the mission, policy and organizational structure of the International Baccalaureate Organization. The IB coordinator exercises the leadership while the IBO offers opportunities for Continuous Professional Development which is a vital aspect of the programme and is compulsory for teachers. The IBO also evaluates the processes followed and outcomes reached. As such, there is clearly an accountability element here which abides by the principles of the organization for international mindedness, reflective learning and personal investigation. Still, the very fact that in Greece these operate in private schools complicates issues of power in the organization with reference to the management of the school that host the programme.

It was hypothesized that the different forms of governance would influence leaders in the ways they exerted leadership as well as teachers in the way they felt about their job. More precisely, the main research question to explore was: "In what ways do differences in leadership exerted in four different types of Greek secondary schools affect teachers' professionalism as reflected in their professional development, perceived efficacy and job satisfaction?"

\footnotetext{
1 In this study, the term "IB Schools" refers only to the IB Diploma Programme addressing 16-18 year olds
}

To respond to the above the following sub questions were formed: How do leaders exercise leadership in the four different types of school and differing systems of governance?

What factors affect the overall qualitative aspects of exercised leadership in the four different schools?

How do the different approaches to leadership influence the learning culture of a school?

What variables may affect teachers' professionalism? It was hypothesized that the highly centralized form of governance in Greek state schools deprives both school leaders of their fundamental role of establishing a pedagogical culture and teachers, of core aspects of their work, such as the sense of control they exert on it (efficacy), job satisfaction and feeling of professional worth. It was further hypothesized that schools that manage to have a degree of autonomy such as the Model schools, Private schools and the IB schools, follow different forms of leadership resulting into qualitative differences in collegiality, shared learning and ethos that may in turn affect quality of schooling.

Finally, based on Evans research on motivational issues among teachers, to teacher professionalism and self-efficacy, it was hypothesized that emphasis on specific aspects of leadership such as distributed or pedagogical leadership empowers teachers in ways that are relevant to the quality of their work, the satisfaction they get out of it and thus their willingness to strive for the best.

\section{Methodology}

\subsection{Design}

The research approach used was a mixed design, that combined aspects of both qualitative and quantitative research. A multi strategy, mixed method design was chosen as the best approach to have a more complete and comprehensive picture of the topic of interest to the investigation [44]. More precisely, a combination of questionnaires and of semi structured interviews addressing the different groups of participants i.e. teachers and Principals were used to explore aspects of leadership and the perceived effects these had on teachers' professionalism. Questionnaires addressed to teachers, encompassed a mixed method using the sequential explanatory model, allowing both closed as well as open responses. This provided the researcher with rich data and enhanced validity of findings [44], [8]. Mixed Methods research is deemed to be the richest in providing data as long as the compatability thesis is well taken in, in other 
words, as long as the mixed design is chosen to actually build on stregths of both positivistic quantitative and qualitative approaches, rather than simply mixing the methods [3]. As a middle way in the two paradigms of positivism and cultural constructivism, adopting mixed methods best fit the scope of this research.

\subsection{Method}

The survey was used as a method to collect views and experiences of participants through questionnaires and interview surveys, having the advantage of a simple approach to the study of values, beliefs and attitudes held [44]. The case study was adopted. An educational case study is localized in both space and time and this is practical as it can focus on the interesting aspects of the research [2]. Seven case studies schools in total were explored, comprised of at least one school from each different type (State, Model, Private, IB). This method, gave the researcher the opportunity to focus entirely on the types of schools of interest and at the same time contextualize the variables, relevant to the research question asked. It also helped to link leadership styles exerted to particular schools and their population.

\subsection{Sample}

In the end, seven Heads in total $(\mathrm{N}=7)$, four coming from State schools and one from each of Model, Private and IB schools took part in the study. An average number of 10 teachers from each type of school responded totaling in a population sample of 44 teachers $(\mathrm{N}=44)$. Questionnaires, were only addressed to teachers and encompassed a mixed method philosophy: They were comprised of ten items that could be single coded and objectively measured, twenty seven items exploring personal interpretation of school reality (school climate, culture of learning, professional development, attitudes, job satisfaction), marked on a five point Likert scale (like agreeing with a statement. eg. "Teachers at this school respect colleagues who are expert in their craft") as well as four open ended questions for items where more elaboration was needed from the part of subjective view of the respondent (perceived needs and support provided) Data from Principals was obtained by means of face to face, semi structured interviews.

\section{Results and Discussion}

With reference to the main hypotheses stated, present findings are in line with Hallinger and Heck [25] and Swaffield and MacBeath's [48] ecological approach and suggest that the different systems of governance seemed to affect the leadership applied in the different types of schools in both subtle and in some more direct ways. Given the complexity of leadership in context, stated by Dempster [12], these differences were found to be mostly qualitative in nature and interwoven with various aspects of exercising leadership in schools. Heads indeed led their schools differently according to the wider system of governance, the powers exerted on them, the specific cultures of the schools as well as the wider organization and structures they followed. There were some elements of leadership that were tightly linked with the wider framework (eg. monitoring teachers' performance, evaluating teachers' work, motivating teachers) while in others, each leader tried to accommodate their school needs in ways that best fit their own micro context. This was evident in the different responses received by Heads, especially with reference to the challenges they felt their teachers faced and the ways they, as Heads, tried to accommodate them. These differences in leadership were also reflected in teachers' professionalism and most importantly manifested themselves in qualitatively varied ways. For example, despite the tight control of the State, State school teachers felt they did have a say over both the curriculum and the educational policy to be followed. This was not expected and in fact sounds oxymorous, since the syllabus is highly prescriptive and directed from the top by the Ministry of Education. As expressed by Georgas et al [22] what happens in reality is that teaching is left to teachers while everyhting else remains under the control of the State. State school teachers nevertheless felt in control with a perceived power over educational policy, probably due to the 'power' they felt was assigned to them. At the same time however, they were the only ones who strongly stated that they had little faith in the teaching profession. Ware and Kitsantas [50] highlighted the importance of perceived efficacy on professional commitment and job satisfaction. In light of their findings it may then be suggested that State school teachers' perceived efficacy might indeed not have been real.

This interpetation may be strengthened by the fact that Model school teachers who also scored high in indicators of efficacy but whose perceived power was differently rooted, did show high ratings in all variables of job satisfaction. Their efficacy relied clearly on the learning philosophy that governs the school rather than any 'rights' assigned to them: Developing own material, methods and activities constitute the cornerstone of the philosophy and work of Model schools while teachers as well as the Head of the school took pride in it. Private school teachers as well as IB teachers felt less able to influence 
educational policy which can be explained by the fact that they are privately owned and constantly accountable to superiors and stakeholders. This also resulted into them experiencing more stress and disappointment compared to State school teachers. Another example of qualitative differences was the degree of synergy felt among teachers. Collegiality was highly valued especially among Model school teachers and this was evidently a reflection of school ethos and leadership. Private school teachers marked strong synergy measures but their responses stemmed from a different source, namely the long term and strong relationships in the school, an indicator of the role years of experience and trust play in schools in line with literature [49], [23]. State schools were least strong in this respect showing moderate responses though still valuing collegiality. It was not clear as to whether this was attributable to leadership, the specific school climate or to the wider Greek culture that values trusting relationships.

This diversity in responses is in line with Day and Summons' claim that there are a number of ways that leadership affects people and sometimes it is difficult to identify the specific variables that have an effect [11]. Overall, Model school teachers were the ones to experience most positive feelings as concerns their work and this was true for all variables measured. Both the Head and the teachers showed strong collegiality ratings, a solid culture of learning and sharply different approaches in how they viewed their professional development. It was the only school where teachers were clear and specific about their development and recognized the efforts put by the leader of the school to support them. Private and IB schools indicated strong collegiality but their direct governance of private Headship had different effects on their perceived job satisfaction, again justifying the importance of context [12], [46].

In line with the OECD reports [40], [41] responses from the Heads clearly reflected the limits or the degrees of freedom they experienced in leading their schools, depending on the system they operate in. "Tied hands" "suffocating" were expressions bitterly mentioned by Heads of State schools indicating their role being restricted by the State to act as managers rather than leaders. In certain variables this was particularly true in a rather dichotomous sense between state and privately funded schools, as in the selection of teaching staff. The unanimous response of State school Heads concerning their inability to select, monitor and motivate their staff, was an example of the centralized, impersonal system of teachers' appointment while the comments that accompanied those responses made by the Heads of State schools reflected their wish to have some say over this. Being leaders, they strongly felt the need to work with people that are in line with the mission of the school they lead and the philosophy they, as leaders of these schools and communities wish to embed. These Heads wished to stimulate collegiality and support and this is in line with what Sergiovanni identifies as mostly needed in schools today [45]. Still, in Greece this was not possible for most of them. Relevant to this was also the issue of monitoring teacher performance and leading and motivating teachers. The fact that the IB school Head was the only one that referred to specific tools of teacher and school evaluation, indicates how, leadership, being interwoven in the system of its governance by the International Baccalaureate Organisation, helped the Head be more knowledgeable of other ways of leading his team to effective schooling practices. However, in making use or actually implementing these, he too was restricted and subject to powers exerted by the private school administration. On the contrary, State school Heads felt invariably helpless in motivating their teachers, which however is perhaps the most salient aspect of school leadership.

The case of Model School Head was interesting and promising, indicating that the approach of leadership chosen in that school has achieved maximum teacher acknowledgement of the efforts of the school to respond to teachers' needs. Model school teachers were the only ones to strongly recognize the support they got from leadership and the efforts made by the school to cater for their needs. It seems therefore as suggested in literature, that effective leadership in this case led to improved quality of learning experience. The interconnection between establishing a mission of the school, freedom assigned to select the staff and the qualitative differences in leadership, reflected Knapp's view of leadership as a "connecting tissue" [30]. More precisely it was noted that moving from a general goal of State schools to "educate young people" towards a focused and clearly expressed school mission as in the case of Model, Private and IB schools, it sounded almost imperative to leaders that teacher selection must satisfy certain criteria. A consequent approach in leading such staff is to both acknowledge their work and provide structural support in the case of difficulties as suggested by Male and Paleologou [34]. This was reported by all Heads but there were differences as to how to act upon it. The Model and the IB schools were the only ones that made explicit reference to strategies and actions such as supportive interventions, mentoring and Professional development opportunities as ways to keep staff motivated and this was also reflected in teachers' positive responses and overall feelings concerning their work and trust to leadership. The IB teachers however were the most disappointed indicating a clear mismatch between 
headship and their perceived reality. State school Heads felt deprived of real power to respond to their teachers' needs. Some transferred responsibility to from Heads, leaving them to only implement top down policies and decisions. Irrespective of system of governance and powers exerted, all Heads were able to "read" both the micro and the macro context of their schools, emphasizing their strong contextual aspect documented in literature [12], [32], [13]. Participant Heads in this study, focused on different aspects of what they considered as important or specific to their community and their mission. For example, the Head of the Modal school emphasized teachers' need for motivation as well as the imperative for innovation following the cornerstone of the pedagogical philosophy of Model Schools. Similarly, the Head of Ag Nikolaos State school, referred to the challenges to accommodate the diversity of the students in his area. Present research also supported the widely held view today, that leadership is more about moral principles and professionalism than any prescriptive theory or style [45]. All Heads assigned priority to ethos and moral leadership, emphasizing aspects of synergy and care. These were constantly referred by both Heads and teachers and acted as a "pillow" in the face of challenges as stated in the majority of participant responses.

Pedagogical leadership seemed to have been a common choice for all Heads despite challenges and this was also well received by teachers, as evident in their responses with variations mainly reflecting the different contexts schools operated. There was a common ground on leadership focusing on learning as suggested by Middlewood and Abbot [36]. All Heads felt strong in most indicators of the embedded learning culture in their schools which implies that they worked hard on this considering it to be their prior responsibility despite the wider governing system. Overall, it seemed that establishing pedagogical leadership [51] allowed the freedom to incorporate the various axes of the social complexities of schooling. Model school teachers showed strong homogeneity in their responses, an indication of the effect of leadership in this school which had obviously succeeded in embedding a solid learning culture. Interestingly, the IB school Head, sounded very disappointed in this respect as if his school had failed to establish a learning culture. His subjective feelings were also reflected in teachers' wide responses, the only ones that showed such big range. Since this is directly in contrast with the IB philosophy and mission, the Head's responses mostly indicate issues of management in the school that hosted the IB programme, also stated in the interview, which again highlights the interconnectedness of leadership and the importance of the social context of the school external services of the governmental system, yet another indicator of the way the Greek centralized way of governance 'steals' important aspects of leadership [12][13]. Focus on learning was highly valued as Professional development opportunities were constantly mentioned as a priority for the schools by both teachers and Heads. Again, there have been variations in this. Professional Development was the least strong variable in ratings in State schools. Heads seemed to be more in line with what literature suggests about exploring forms of effective CPD \{16], [24]. Interestingly, the whole group of State school teachers gave high ratings $(100 \%)$ in evaluating professional development opportunities, which contradicted later open responses, a fact that probably indicates that they could not really judge the overall quality or that they answered in a socially desirable manner. Another interesing finding was that in identifying the challenges teachers were faced with, system of governance was mentioned by all, except the State school teachers. This was thought to be indicative of how State teachers have internalised the strong and direct guidance from the Ministry. Closely related to this, State school teachers relied heavily on external help from the State, in meeting challenges, indicating the effect of the system of governance which directs action to external State authorities rather than the leader. On the contrary, Model school teachers referred strongly to their Head as the main source of support which shows the difference of leadership applied in this school. The fact that IB school teachers felt almost hopeless can be explained by the conflicting powers exercised in the particular school where the IB leadership was undermined by the hosting school Headship.

\section{Conclusion and Recommendations}

Based on the present findings the following recommendations can be made: This study is in line with suggestions made in OECD reports [39], [40], [41] and argues that Leaders in Greek schools should be given both the necessary training and the opportunity to exercise leadership allowing them the freedom to actually lead rather than simply manage and apply decisions imposed by the State. This probably means also freedom to take risks and be accountable for. Although accountability is still debated as a factor of school improvement, professionalism is clearly needed and a conscious effort to enhance it must be embedded in the wider school system. Ineffective or masked structures that only in theory devolve power to schools must give way to true devolution. On the other hand, as suggested by Hanson [26] this needs be carefully and strategically built taking into consideration the wider 
context as well as the perils of "toxic leadership" [10]. A continuum of school autonomy and control combined with effective moral leadership and strong ethos as was the case in Model school in this study can be a good exemplar to try out in Greek secondary schools. Systems must also ensure qualitative and effective professional development actions for all teachers as a way to improve quality of teaching and learning. Overall, it is suggested that leading schools is very important and its significance increases as we move to more complex societies. Greece is a country that faces considerable challenges in trying to adjust education to the new era and respond to dramatic changes in student population in the past fifteen years, heightened today with the refugee crisis. Above all, schools are places where young people build dreams that lead to the future. Their own and the world's. It is imperative that the Greek State caters for their needs by building good schools that promote learning for all and has a positive effect on students' lives.

\section{References}

[1] Bass, B.M. and Avolio, B.J. (1994) Improving Organizational Effectiveness Through Transformational Leadership. Thousand Oaks, Sage.

[2] Bassey, M. (2012) "Case Studies" in: Briggs, A., Coleman, M. and Morrison, M. (eds), Research Methods in Educational Leadership and Management. 1st ed. London: SAGE publications.

[3] Briggs, A., Coleman, M. and Morrison, M. (eds) (2012) Research Methods in Educational Leadership and Management. 1st ed. London: SAGE publications.

[4] Buck, A. (2016) Leadership Matters. Woodbridge: John Catt Educational Ltd.

[5] Bush, T. (2009) 'Leadership Development and School Improvement: Contemporary Issues in Leadership Development' Educational Review, Vol. 61, No. 4, pp 375389.

[6] Cheng, Y. C. (1991) 'Leadership style of Principals and organizational process in secondary schools' Journal of Educational Administration, 29(2), pp 25-37.

[7] Coelli, M. and Green, D.A. (2012) 'Leadership Effects: School Principals and Student Outcomes'Economics of Education Review, Vol.31 (1), pp 92-109.

[8] Cohen, L., Manion, L. and Morrison, K. (2005). Research Methods in Education. 5th ed. London: Routledge Falmer.

[9] Coleman, M. (2012) in: Briggs, A., Coleman, M. and Morrison, M. (eds) Resarch Methods in Educational Leadership and Management,.1st ed. London: SAGE Publications.
[10] Craig, I. (2017) 'Toxic leadership' in Greany, T. and Earley, P. (eds) School Leadership and Education System Reform. London: Bloomsbury Academic.

[11] Day, C. , Gu, Q., Sammons, P., (2016) 'The Impact of Leadership on Student Outcomes: How Successful School Leaders Use Transformational and Instructional Strategies to Make a Difference', Educational Administration Quarterly, Vol.52(2), pp 221-258.

[12] Dempster, N. (2009) 'What Do We Know About Leadership?' in MacBeath, J. and Dempster, N. Connecting Leadership And Learning. Principles for practice. London: Routledge.

[13] Dempster, N. and Bagakis, G. (2009) "Leadership for Learning: Towards a Practical Theory" in MacBeath, J. and Dempster, N., Connecting Leadership And Learning. Principles for practice. London: Routledge.

[14] Earley, P. (2017) 'Conceptions of Leadership and Leading the Learning', in Greany, T. and Earley, P. (eds) School Leadership and Education System Reform. London: Bloomsbury Academic.

[15] Earley, P. (2013) Exploring the school leadership landscape. London: Bloomsbury.

[16] Earley, P. and Porrit, V. (2009) Effective Practices in Continuing Professional Development: Lessons from Schools. London: IOE Publications.

[17] Eberts, R. and Stone, J. (1988) 'Student Achievement in Public Schools: Do Principals Make A Difference?' Economics of Education Review, Vol. 7, No. 3 pp 291-299.

[18] Evans, L. (2003) 'Managing Morale, Job Satisfaction and Motivation' in Davies, B. and West_Burnham, J. (eds) Handbook of Educational Leadership and Management. London, Pearson.

[19] Freire, P. (1986) Pedagogy of the Oppressed. New York: Continuum.

[20] Fullan, M. (2009) 'Leadership Development: The Larger Context' Educational Leadership, Vol.67 (2) pp 45 49.

[21] Fullan, M. (2003) The Moral Imperative of School Leadership, Thousand Oaks, CA: Corwin Press.

[22] Georgas, T., Tsigou, P. Giannoukos, G. (2015) 'How Teacher Professionalism Struggles to Survive within the Greek Secondary Education System' International Education and Research Journal, Vol, 1, No 4 pp 4 - 9.

[23] Gronn, P. (2003) The New Work of Educational Leaders: Changing Leadership Practices in an Era of School Reform, London: Paul Chapman.

[24] Guskey,T. (2002) 'Does it Make a Difference? Evaluating Professional Development', Educational 
Leadership, March, pp. 45-51 Available in Online Library Academic Search Complete.

[25] Hallinger, P. \& Heck, R. (1998) 'Exploring the Principal's Contribution to School Effectiveness: 1980 1995, School Effectiveness and School Improvement': An International Journal of Research, Policy and Practice, 9:2, pp157-191. Available at http://dx.doi.org/10.1080/0924345 980090203 (Accessed on 2 April 2017).

[26] Hanson, E.M. (1998) 'Strategies of Educational Decentralization: Key Questions and Core Issues', Journal of Educational Administration, 36 (2), pp 111 - 128.

[27] Hargreaves, A. (2007). 'Sustainable Leadership and Development in Education: Creating the Future, Conserving the Past' European Journal of Education,Vol. 42, No. 2, Hargreaves, A. and Fink, D. (2006) Sustainable Leadership. San Francisco: Jossey Bass.

[28] Harris, A. and Anthony, P. (2001) 'Collegiality and its Role in Teacher Evaluation: Perspectives from Veteran and Novice Teachers', Teacher Development, 5(3) pp 371-89.

[29] Institute of Education (2012a) Leading and Managing Educational Change and Improvement. London: University of London Press.

[30] Institute of Education (2012b) Leadership for the Learning Community. London: University of London Press.

[31] Levacic, R. (2002) 'Efficiency, Equity and Autonomy' in Bush, T. and Bell, L. (eds) The Principles and Practice of Educational Management, pp 101-202.

[32] MacBeath, J. and Dempster, N. (2009). Connecting Leadership And Learning. Principles for practice London: Routledge.

[33] Male, T. (2015) 'Pedagogical leadership in the 21st century' Educational management, administration \& leadership (1741-1432), 43 (2), p. 214

[34] Male, T. and Palaiologou, I. (2015) 'Pedagogical leadership in the 21 st century' Educational Management Administration \& Leadership, 43(2), pp.214-231.

[35] Malinen O.P. and Savolainen, H. (2016) 'The effect of perceived school climate and teacher efficacy in behavior management on job satisfaction and burnout: A longitudinal study' Teaching and Teacher Education, v60, pp 144-152.

[36] Middlewood, D. and Abbot, I. (2015). Improving Professional learning Through In - House Inquiry. London: Bloomsbury Academic.

[37] Mulford, B. (2008) 'Section 4: Leaders' in The Leadership Challenge: Improving learning in schools, Victoria: Acer Press P2, pp. 38-66 Available at www.acer.edu.au.

[38] Mulford, B., Kendall, D.,Edmunds, B., Kendall, L., Ewington, J., Silins, H. (2007) 'Successful school leadership: what is it and who decides?' Australian Journal of Education (ACER Press), Vol.51 (3), pp.228-247.

[39] OECD PROJECT (2011) Overcoming School Failure. Policies that work. Country Background Report, Ministry of Education Life Long learning and Religious Affairs, Athens. Available at https://www.oecd.org/edu/school/49528233. pdf (Accessed on 27 October 2017).

[40] OECD (2011), Education Policy Advice for Greece, Strong Performers and Successful Reformers in Education, OECD Publishing. Available at http://dx.doi.org/10.1787/ 9789264119581-en, (Accessed on 12 September 2017).

[41] OECD (2017) Educational Policy in Greece. A Preliminary Assessment, OECD Publishing. Available at http://www.oecd.org/edu/Education-Policy-in-GreecePreliminary-Assessment-2017.pdf, (Accessed on 26 October 2017).

[42] Porrit, V., Spence-Thomas, K., Taylor, C. (2017) 'Leading Professional Learning and Development' in Earley, P. and Greany, T. School Leadership and Education System Reform. London, Bloomsbury.

[43] Robinson,V. (2011) Student Centered Leadership, San Francisco, Jossey - Bassey.

[44] Robson, C. and McCartan, K. (2016) Real World research $4^{\text {th }}$ ed John Wiley and Sons Limited, Chichester.

[45] Sergiovanni, T. J. (2007). Rethinking Leadership. USA: Corwin press. $2^{\text {nd }}$ edn.

[46] Sergiovanni, T. (2001) Leadership. What's in it for Schools? London: Routledge/Falme.

[47] Sahlberg, P. (2007). Education policies for raising student learning: the Finnish approach. Journal of Education Policy, 22(2), pp 147-171.

[48[ Swaffield, S. and MacBeath, J. (2009). 'Leadership for learning' in MacBeath, J. and Dempster, N. (eds) Connecting Leadership And Learning. Principles for Practice, London: Routledge. pp 32-52.

[49] Van Maele, D. Van Hutte, M. (2012) 'The role of teacher and faculty trust in forming teachers' job satisfaction: Do years of experience make a difference?' in "Teaching and Teacher Education pp.879-889.

[50] Vidoni, D. Bezzina, C. Gatelli, D., Grassetti., L. The Role of School Leadership on Student Achievement: Evidence from Timss 2003, European Commission JRC, JRC42802, EUR 23072 EN, Luxembourg: Office for Official Publications of the European Communities available at http://europa.eu/ (accessed on April 2017).

[51] Ware H., and Kitsantas, A., (2007) Teacher and Collective Efficacy Beliefs as Predictors of Professional Commitment, The Journal of Educational Research, 100:5, pp 303-310, DOI: 10.3200/JOER.100.5.303-310 Available 
International Journal of Innovative Business Strategies (IJIBS), Volume 6, Issue 1, 2020

at:http://dx.doi.org/10.3200/JOER.100.5.303-310

(Accessed 30 October 2017).

[52] Webb, R. (2005) "Leading Teaching and Learning in the Primary School. From Educative Leadership to Pedagogical Leadership' Educational Management Administration \& Leadership, Vol.33 (1), pp.69-91 